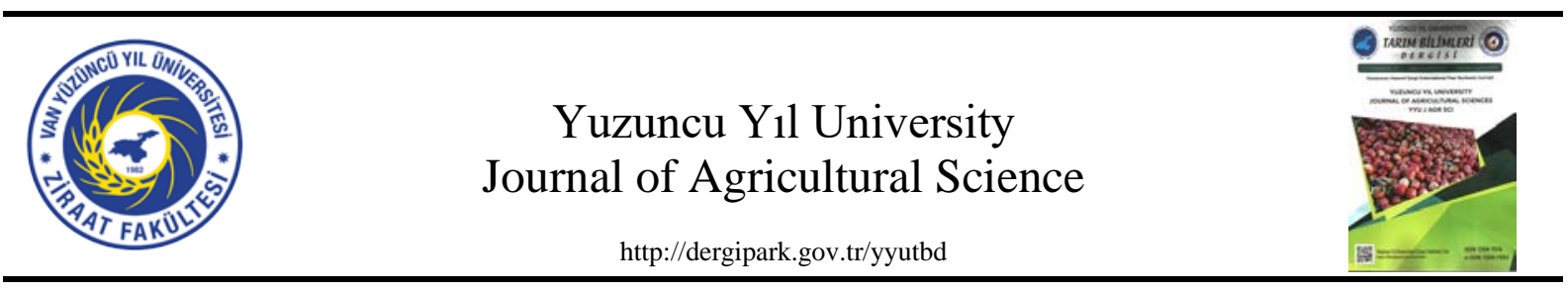

Araştırma Makalesi (Research Article)

Investigation Tine Type Effect on Soil Fragmentation for Conservation Tillage Gholamhossein SHAHGHOLI $^{* 1}$, Abdolmajid MOINFAR ${ }^{1}$

${ }^{1}$ University of Mohaghegh Ardabili, Faculty of Agriculture and Natural Resources, Department of Biosystems

Engineering, Ardabil, Iran

*Corresponding authore-posta: gshahgoli@yahoo.com

\section{Article Info}

Received: 13.05.2019

Accepted: 15.07.2019

Online Published 30.09.2019

DOI: 10.29133 yyutbd.564789

\section{Keywords}

Mean weight diameter,

Paraplow,

Subsoiler tine,

Soil aggregate.

\begin{abstract}
One of the main aims of tillage operation is to provide a seedbed with appropriate soil fragmentation and to create relatively large aggregates of topsoil to achieve conservation tillage. Considering that subsoiling is necessary for hardpan breakup, the creation of a seedbed with the same operation can increase the operation efficiency. The present study was conducted to investigate the effect of tine type on soil aggregate. For this purpose, we tested four subsoiling tines of conventional, Bentleg, Paraplow, and winged-Paraplow in the field at soil moisture contents of $8,12,16$, and $20 \%$ and the tractor forward speeds of $0.5,1$, 1.2 , and $1.4 \mathrm{~m} / \mathrm{s}$. Soil fragmentation was evaluated in different depths of 10,20 , 30 , and $40 \mathrm{~cm}$. Winged-Paraplow and Paraplow, compared with two other tools, showed more soil disturbance due to having a wing and chisel at the end of the tine. The highest mean weight diameter (MWD) $=19.9 \mathrm{~mm}$ was reached using a Bentleg at a depth of $10 \mathrm{~cm}$ and moisture content of $20 \%$. In comparison, the lowest value of $3.37 \mathrm{~mm}$ was related to the winged-Paraplow at a depth of $40 \mathrm{~cm}$ and moisture content of $8 \%$.Considering the aggregate size of $0.5-8 \mathrm{~mm}$ for providing a proper seedbed, the winged-Paraplow tine is a suitable tool that can provide seedbed at any depth at a water content of 0.8PL, where PL denotes plastic limit. At slow forward speeds, fine particles had enough time to sift to a deeper layer, which is beneficial for seedbed creation. Reducing the soil moisture increased soil disturbance and its fragmentation. Moreover, it was observed that MWD was higher at high moistures..
\end{abstract}

\title{
Koruyucu Toprak İşlemesinde Dipkazan Tipinin Toprak Parçalanması Üzerindeki Etkisinin Araştırılması
}

\section{Makale Bilgileri}

Geliş: 13.05.2019

Kabul: 15.07.2019

Online Yayınlanma 30.09.2019

DOI: 10.29133/yyutbd.564789

\section{Anahtar kelimeler}

Ortalama ağırlık çapı,.

Paraplow,

Dipkazan,

Toprak agregasi.
Öz: Toprak işleme operasyonunun temel amaçlarından biri, uygun toprak parçalanmasına sahip bir tohum yatağı sağlamak ve koruyucu toprak işlemesi için nispeten iri agregata sahip bir üst toprak oluşturmaktır. İşlenmemiş sert toprağın kırılması için derin sürümün gerekli olduğu göz önüne alındığında, aynı işlemle bir tohum yatağı oluşturulması işlem verimliliğini artırabilir. $\mathrm{Bu}$ çalışma, dipkazan tipinin toprak agregası üzerindeki etkisini araştırmak amacıyla yapılmıştır. Bunun için dört toprak altı dipkazanı (Konvansiyonel, Bentleg, Paraplow ve kanatlı Paraplow), farklı toprak nemi içeriğinde (\%8, $\% 12, \% 16$ ve \%20) ve faklı traktör hizlarında $(0.5,1,1.2$ ve $1.4 \mathrm{~m} / \mathrm{s})$ test edilmiştir. Toprak parçalanması, farklı derinliklerde $(10,20,30$ ve $40 \mathrm{~cm}$ ) değerlendirilmiştir. Diğer iki araçla karşılaştırıldığında, Kanatlı-Paraplow ve Paraplow, dipkazan sonunda bir kanat ve keski olması nedeniyle daha fazla zemin örselenmesi göstermiştir. En yüksek ortalama ağırlık çapına [(MWD) = $19.9 \mathrm{~mm}$, Bentleg ile $10 \mathrm{~cm}$ derinlikte ve \%20 nem içeriği kullanarak ulaşılmıştır. Bununla birlikte en düşük değer $(3.37 \mathrm{~mm}), 40 \mathrm{~cm}$ derinliğindeki 
kanatlı Paraplow ve nem içeriği \%8 ile elde edilmiştir. Düzgün bir tohum yatağ sağlamak için 0.5-8 mm agrega büyüklüğü göz önüne alındığında, $0.8 \mathrm{P}$ ( $\mathrm{PL}=$ Zeminin plastisite limiti) su içeriğinde herhangi bir derinlikte tohum yatağ sağlayabilmede kanatlı-Paraplow dipkazanı uygun bir araçtır. Yavaş ileri hızlarda, ince parçacıklar daha derin bir tabakaya elenmek için yeterli zamana sahiptir; bu da tohum yatağı oluşturma için faydalı olmaktadır. Toprağın nemini azaltmak, toprağın bozulmasını ve parçalanmasını artırmaktadır. Ayrıca, MWD'nin yüksek nemlerde daha yüksek olduğu gözlenmiştir.

\section{Introduction}

In the semi-arid regions of Iran, crop production in dryland farming has decreased significantly due to rainfall shortage in recent years. In this regard, conventional tillage using moldboard plows can cause loss of moisture and soil erosion. Conventional plowing causes excessive crumbling of soil and, on the other hand, leaves a small amount of residue on the surface of the soil, leading to excessive evaporation and wind erosion (Barzegaret et al., 2003). Conservation soil by means of chisel plow disturbs the soil surface less, leaves more crop residue on the soil surface, and reduces the loss of moisture and soil erosion (Czyż and Dexter, 2009). Due to the disadvantages of conventional tillage and the benefits of conservation tillage in dryland and semi-arid areas, an increasing trend has been recently evidenced from conventional tillage to conservation tillage (Dalla Rosa et al., 2012). Therefore, it is necessary to evaluate the soil structure after the operation with conventional tillage implement to find optimal operational and farm conditions.

Appropriate particle size is a very important factor in plant growth and soil conservation. Many studies have reported that having a particle size less than $1 \mathrm{~mm}$, because of increasing soil contact with the seed, is essential to increase the emergence of seeds (Murungu et al., 2003). Murungu et al. (2003) investigated the effect of four aggregate sizes of 4.75-16, 2-4.75, 1-2, and $<1 \mathrm{~mm}$ on the emergence of primed and non-primed cotton and maize at different initial matric potentials. The aggregate size plays a key role in seed emergence, shoot length, and root length such that the aggregate size less than $2 \mathrm{~mm}$ leads to greater emergence and better early seeding growth than larger aggregate sizes. Also, a particle size less than $0.4 \mathrm{~mm}$ leads to better plant placement, because smaller particles can be put together more uniformly and evenly; however, large particles may have asymmetrical shapes and cannot create a smooth surface (Nasr and Selles, 1995). Russell (1973) concluded that the particle size between 1-5 mm provides the best situation for plant establishment. Hakansson et al. (2002) suggested that having at least $50 \%$ of particles below $5 \mathrm{~mm}$ would contribute to the growth and development of plant root. Munkholm (2002) observed that when a large proportion of particles have a size range of $0.5-1 \mathrm{~mm}$, the risk of increasing wind and water erosion is alarming. On the other hand, particle size greater than $8 \mathrm{~mm}$ disrupts plant development due to the reduction of root-soil contact. In many studies, it has been reported that the optimum seedbed should have particles in the size range of 0.5 to $8 \mathrm{~mm}$ such that they can simultaneously provide a suitable seedbed for root development and prevent wind and water erosion (Braunack and Dexter, 1989; Berntsen and Berre, 1993; Abbaspour-Gilandeh and Sedghi, 2015;).

Salaret al. (2013) studied the behavior of three types of subsoiler and chisel tines in the deep conservation tillage. In this research, the lowest MWD was obtained when the forward bent tine was applied with a rake angle of $7.5^{\circ}$ and a bend angle of $10^{\circ}$. MWD of dual bent tines was significantly smaller than the winged chisel plow. Soil water content had a significant effect on both MWD and the amount of residues on the soil surface during tillage with a chisel; however, no significant effect was observed as tillage was performed using the dual-bent tine implement. Gill and McCereery (1960) conducted extensive research on the effects of tool width on quality of mechanical disturbance of the soil. They used moldboard plows to cut the soil, which was performed at a depth of $17 \mathrm{~cm}$ in a clay loamy silty soil with an average moisture content of $14 \%$ and a speed of $1.3 \mathrm{~m} / \mathrm{s}$. Plows had 5 different widths from 2.5 to $20.3 \mathrm{~cm}$. After cutting the soil by each tool, the disturbed soil aggregates were separated from each other by means of a rotating sieve. The results showed that narrower plows disintegrated soil particles into smaller units. Slowinska (1994) discussed the effects of different tillage systems on the physical properties of the soil and concluded that the use of different tillage equipment would alter the soil structure through pulverizing the soil, changing the structure or size of 
the porosity, and arrangement of soil particles. All of these processes lead to a major change in other physical properties of the soil. Woodruff et al. (1986) reported that when the speed of a chisel plow increased from 0.8 to $1.4 \mathrm{~m} / \mathrm{s}$ in a silty loamy soil, the diameter of the clods larger than $19 \mathrm{~mm}$ was reduced by $10 \%$. Also, by increasing the depth of tillage during the operation, the amount of soil crumbling significantly decreased. Ojenigi and Dexter (1979) reported that suitable moisture for tillage operations was 0.9 of soil plastic limit (PL), which leads to the formation of small aggregates and the lowest proportion of large clods. Ahmadi and Mollazadeh (2009) investigated the effect of two plow depths of $15-20$ and $25-30 \mathrm{~cm}$ and four moisture contents of 10-13, 13-15, 15-18, and 18-20\% based on dry weight on MWD during operations of moldboard plow. They reported that the smallest clods were created at 20-25 cm depth and moisture of 18-20\%. Kabiri and Zarean (2002) studied the effect of tillage depth and forward speed of tractors on the size of created clods and the amount of buried plant remaining during the moldboard plow operations. According to these researchers, with an increase in tillage speed, the plant beds were more uniform, the amount of soil crumbling was improved, and more plant remnants were buried. Barzegar et al. (2004) conducted another study on the interactive effects of tillage system and soil water content on aggregate size distribution for seedbed preparation in two soil types in the southwest of Iran. They showed that the aggregate size distribution was altered due to different tillage systems, soil moisture change, and different textures.

The present study was conducted to determine soil fragmentation created by different types of subsoiler tines at different moisture levels and different depths during conservation tillage operations.

\section{Material and Methods}

Experiments were carried out at the research field of Mohagheg University (48 $55^{\prime} 47^{\prime \prime} \mathrm{E}$ and $37^{\circ} 33^{\prime} 57^{\prime \prime} \mathrm{N}$ and an altitude of $1352 \mathrm{~m}$ above sea level) with a soil texture of loam containing clay, silt, and sand contents of $25 \%, 29.3 \%$, and $45.6 \%$, respectively. The site had a 0 to $1 \%$ slope and had barley stubble residues from the previous farming season. Its liquid limit (LL) and plastic limit (PL) values were $46.32 \%$ and $23.27 \%$, respectively. A RIMIK digital penetrometer (CP20) was used to measure penetration resistance. Penetration resistance was randomly measured at 20 locations over 0 $40 \mathrm{~cm}$ depth from $0 \mathrm{~cm}$ level (ground surface). Also bulk density in soil layers (10, 20, 30 and $40 \mathrm{~cm}$ ) was measured using the standard cylindrical cores. Soil bulk density and penetration resistance at moisture content of $8 \%$ and for soil layers $(10,20,30$ and $40 \mathrm{~cm})$ in Table 1 are presented. The experiments were conducted in a completely randomized block design with three replications. The treatments included four different subsoiling tines of conventional, Bentleg, Paraplow, and wingedParaplow (Fig. 1), which were tested at the tractor forward speeds of $0.5,1,1.2$, and $1.4 \mathrm{~m} / \mathrm{s}$ and gravimetric water content of $8,12,16$, and $20 \%$ (d.b.). These moistures represent average soil moisture over the depth of $0-40 \mathrm{~cm}$. After irrigation soil moisture was measure every day and after reaching to desired moisture, tests were conducted in corresponding treatments. As moisture was decreased gradually accomplishment of tests was completed. All tests were carried out under PL and the maximum moisture was -0.86 PL. Soil fragmentation was evaluated at depths of 10, 20, 30, and 40 $\mathrm{cm}$.

Table 1. bulk density and penetration resistance in soil layers

\begin{tabular}{llll}
\hline soil layers $(\mathrm{cm})$ & Soil bulk density $(\mathrm{kg} / \mathrm{m} 3)$ & penetration & resistance \\
\hline $0-10$ & 1320 & 435 \\
$10-20$ & 1370 & 1164 \\
$20-30$ & 1410 & 1890 \\
$30-40$ & 1460 & 2135 \\
\hline
\end{tabular}




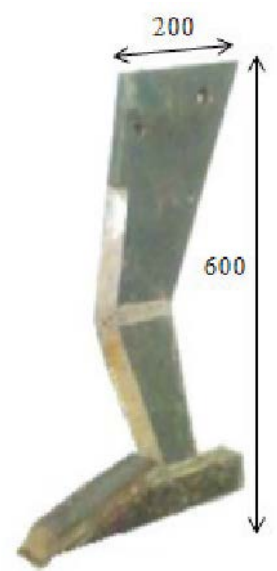

a) paraplow

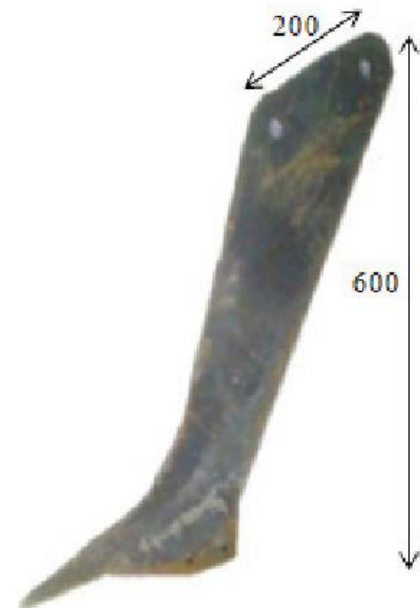

c) conventional

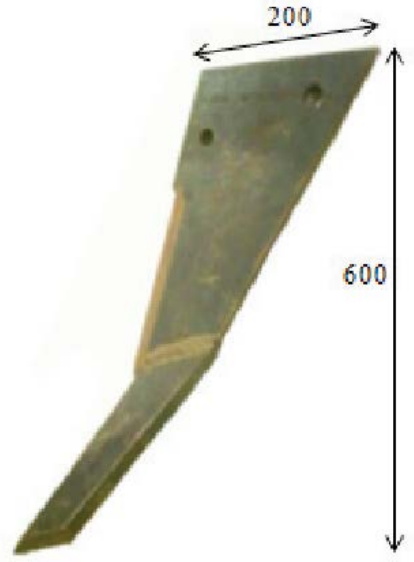

b) bentleg
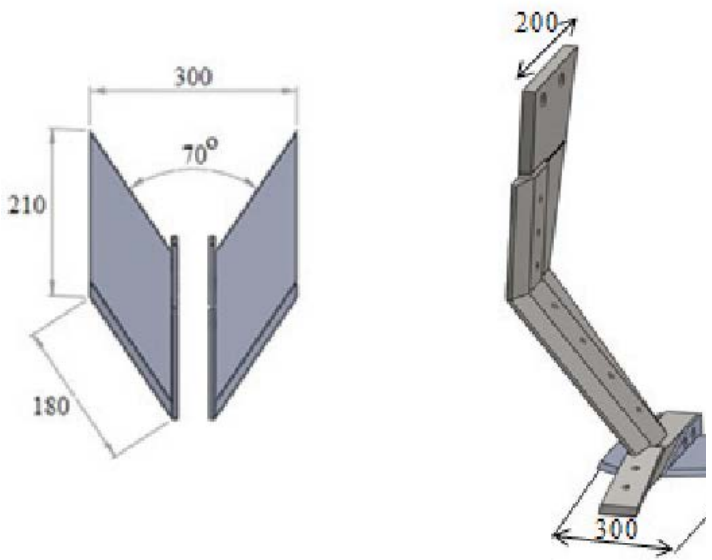

d) winged paraplow

Figure 1. Different tines of bentleg, paraplow, winged paraplow and conventional tines were used in trials.

For these tests, an MF285 tractor equipped with single rear wheels (18.4R30 radial-ply) and a weight of $1694 \mathrm{~kg}$ on the rear axle was used. The inflation pressure of the rear wheel was $100 \mathrm{kPa}$ during all tests. Experimental tests were randomized and blocked to control variation. Then, analysis of variance (ANOVA) was performed on these data. When the effect of any parameter was significant, the means were compared using the least significant difference (LSD) test at a 5\% significance level. The statistical analyses were performed using the statistical package for the social sciences (SPSS 21) software (Ling and Roberts, 1975).

After each test, soil samples were manually collected from the depths of 10, 20, 30, and $40 \mathrm{~cm}$ at three points of tine passing route. Sampling was done by a $50 \times 50 \mathrm{~cm}$ wooden interweaved frame. A steel cylindrical sampler with a diameter of $250 \mathrm{~mm}$ and a height of $400 \mathrm{~mm}$ was designed and made for sampling from deep soil layers. Afterward, the sampler was graded. This graded sampler had 5 layers with $50 \mathrm{~mm}$ height for each layer and, after tillage, the sampler was taken down to the determined point in order to get the soil of each layer. Next, the samples were air-dried for a while so that soil moisture was decreased to desired value of $5 \%$ in which soil is proper for sieving (Adam and Erbach, 1992). Dried soil samples were subsequently hand shaken through 7 sieves with 3.35, 6.35, 13.5, 16, 25.4, 32, and $50.8 \mathrm{~mm}$ mesh sizes for 30 seconds (Salar et al., 2013; Adam and Erbach, 1992). Laboratory sieve shaker of model 730 MM ESSA AUSTRALIA was used for soil screening (Timer Range (99 min), Vibrational Frequency (3600 VPM) and Frequency (60 taps/min)).Mesh openings were chosen based on clod diameters (Kemper and Chepil, 1995). The soil remaining on each sieve was weighed and the clod MWD for each soil sample was calculated using Eq. (3).

$$
\operatorname{MWD}=\sum_{\mathrm{i}=1}^{\mathrm{n}}(\mathrm{Xi} \times \mathrm{Wi})
$$


Where MWD is the clod mean weight diameter for soil sample (mm), Xi is the mean diameter of the holes of the ith sieve and the upper sieve $(\mathrm{mm})$, and Wi is the clod weight ratio of clod remaining on the $\mathrm{i}^{\text {th }}$ sieve as a proportion of the total dry weight of the sample (Adam and Erbach, 1992)

\section{Results}

The ANOVA results and the interaction effects of moisture, speed, depth, and tine type on MWD are presented in Table 2. As can be seen, changes in the factors mentioned had a significant effect on MWD and their interaction effects were significant on MWD at a probability level of $1 \%$.

Table 2. Anova statistics for the effect of moisture, speed, type of tineand depth on MWD.

\begin{tabular}{|c|c|c|c|c|}
\hline Factor & DOF & $\begin{array}{l}\text { Sum of } \\
\text { squares }\end{array}$ & Mean square & $\mathrm{F}$ \\
\hline block & 2 & 0.0 & 0.02 & $0.44^{\mathrm{ns}}$ \\
\hline Tine & 3 & 2850.1 & 950 & $14644^{* *}$ \\
\hline Depth & 3 & 2066.8 & 688 & $42316^{* *}$ \\
\hline Moisture & 3 & 5972.4 & 1990 & $506^{* *}$ \\
\hline Speed & 3 & 71.5 & 23.83 & $210^{* *}$ \\
\hline Tine $\times$ Depth & 9 & 89.3 & 9.92 & $258^{* *}$ \\
\hline Tine $\times$ moisture & 9 & 109.5 & 12.16 & $13.37^{* *}$ \\
\hline Tine $\times$ speed & 9 & 5.7 & 0.63 & $93.05^{* *}$ \\
\hline Depth $\times$ moisture & 9 & 39.4 & 4.38 & $172.62^{* *}$ \\
\hline Depth $\times$ speed & 9 & 72.9 & 8.11 & $15.80^{* *}$ \\
\hline Moisture $\times$ speed & 9 & 120.5 & 13.39 & $284.61^{* *}$ \\
\hline Tine $\times$ Depth $\times$ moisture & 27 & 50.6 & 1.87 & $39.13^{* *}$ \\
\hline Tine $\times$ Depth $\times$ speed & 27 & 13.3 & 0.49 & $10.55^{* *}$ \\
\hline Tine $\times$ moisture $\times$ speed & 27 & 5.4 & 0.2 & $4.25^{* *}$ \\
\hline Depth $\times$ moisture $\times$ speed & 27 & 57 & 2.11 & $44.85^{* *}$ \\
\hline Tine $\times$ Depth $\times$ moisture $\times$ speed & 81 & 24.7 & 0.31 & $6.49^{* *}$ \\
\hline Error & 510 & 24 & 0.05 & \\
\hline Total & 767 & 11573 & & \\
\hline
\end{tabular}

\section{The Triple Effect of Moisture $\times$ Depth $\times$ Tine type on soil fragmentation}

Fig. 2 presents the triple effect of moisture $\times$ depth $\times$ tine type on MWD. With increasing moisture, MWD increased in all depths. For Winged-Paraplow, Paraplow, and Bentleg, the trend of MWD variation with increasing moisture at the depth of $40 \mathrm{~cm}$ was more intense and it increased to a steeper slope. In comparison, in the conventional tine, the trend of MWD change was similar in all depths. Bentleg showed a low sensitivity to moisture increase and MWD change.

The highest MWD of $19.9 \mathrm{~mm}$ was achieved using Bentleg at a depth of $10 \mathrm{~cm}$ and moisture content of $20 \%$, while the lowest value of MWD $=3.37 \mathrm{~mm}$ was related to the winged-Paraplow at a depth of $40 \mathrm{~cm}$ and moisture content of 8\%. Different MWD of 3.37, 4.48, 8.77, and $12.22 \mathrm{~mm}$ were created at different moistures of $8,12,16$, and $20 \%$. With considering MWD of $0.5-8 \mathrm{~mm}$ as criteria, winged-Paraplow is a proper solo tool for creating seedbed at moisture contents less than $16 \%$ (0.8PL). MWD was $8 \mathrm{~mm}$ at the depth of $0.2 \mathrm{~m}$, which is a proper aggregate for seedbed. In general, winged-Paraplow and Paraplow, compared with two other tools created, showed severe soil structure disturbance due to having a wing and chisel at the end of the tine. Using these tines results in small aggregate sizes and provides better seed-soil contact, more rapid water uptake, and better germination. Some research results showed that direct seed-soil contact is relatively unimportant in the absorption of moisture by seeds and water transform in vapor plays a dominant role (Murungu et al., 2003). In this case, fine particle size decreases air movement around small aggregates and pores, leading to fast seed germination. They concluded the aggregates with a size of 1-5 $\mathrm{mm}$ will block larger pores and thus are optimal for seed emergence. 

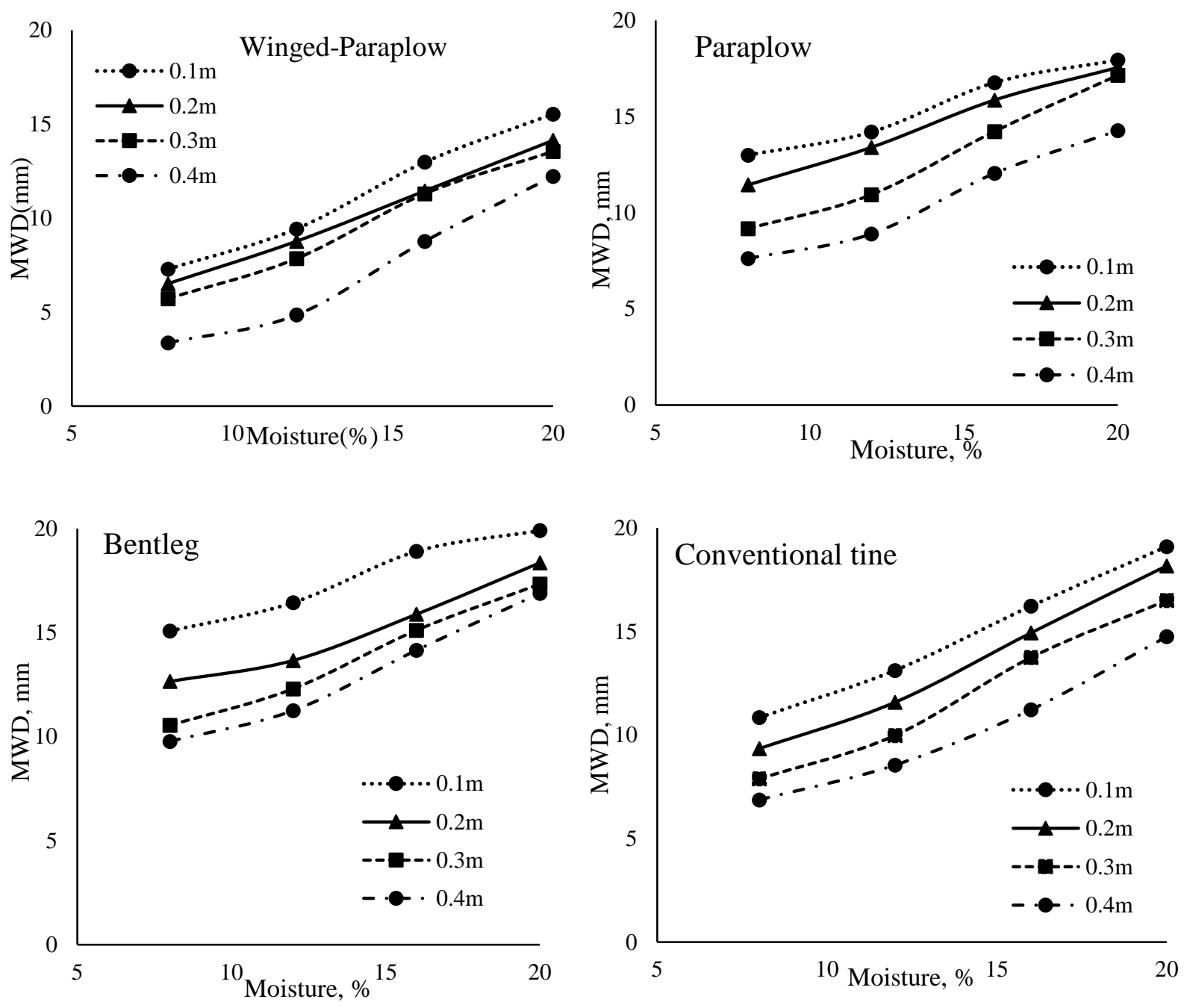

Figure 2. The triplet effect of Moisture×depth×tine type on MWD.

According to Ojenigi and Dexter (1979), the arrangement of aggregates affects the porosity and the surface roughness depends on soil water content at the time of tillage. They found that to produce aggregate in the range of about $4 \mathrm{~mm}$, water content on loam soil should be 1.04PL, while for producing large aggregates and voids larger than $8 \mathrm{~mm}$ soil water content should be increased to 1.19PL. Moreover, they reported that a large portion of small aggregates occurred at a moisture of 0.87 PL. Allmaras et al. (1969) concluded soil aggregate and soil roughness were the minimum when tillage conducted moisture content was equal to the PL. Barzegar et al. (2004) showed that the proper soil moisture for creating an aggregate size of less than $5 \mathrm{~mm}$ depends on soil texture and tillage implement type. The greatest portion of small aggregates $(<5 \mathrm{~mm})$ was produced for Moldboard plow followed by offset disking (MD) and offset disking followed by disc (DD) at 0.8PL and for disc tillage followed by offset disc (DO) at 0.7PL for silty clay loam texture. The corresponding values were 0.7PL for MD and DD and 0.8PL for DO in the loam soil.

Bentleg penetrated to the soil easier compared to the conventional tine due to the low rake angle and. As a result, a low soil disturbance occurred, so the value of MWD was higher (Askari et al., 2019). The soil fractionation rate depends on the rake angle of the Bentleg tine (Fig. 2). Low rake angle improved the soil segregation because these tines tend to lift more coarse clods to the soil surface and create larger voids and clod in surface layers and the small particles sifted and transferred downward the subsoil layers (Heege, 2013). Godwin (2007) showed that the force required to move the tine in soil increases by increasing the rake angle, leading to more soil to be crushed. Such a trend was also reported in the work of other researchers (McKyes, and Maswaure, 1997; Salar et al. 2013). 


\section{Effect of speed $\times$ depth $\times$ type of tine on MWD}

As shown in Fig. 3, the MWD was reduced by increasing the depth for all speeds in all tines type. Sorting of coarse fragments upward and fine fragments downward were presented as the main goal in seedbed preparation (Barzegar et al., 2004). They found that for loam soil at a water content of $0.8 \mathrm{PL}$, a greater portion of soil clods was in the surface layer $(0-10 \mathrm{~cm})$, while the distribution of small aggregates showed their concentration in the bottom layer of 20-25 cm. The variation of MWD with an increase in forward speed at the depths 10 and 20 was almost constant, but it was considerably high at the depths 30 and $40 \mathrm{~cm}$. When cutting the soil at low speeds, finer particles showed a better chance than the larger ones to sift downward the voids; i.e., back of the tines. As a result, a large number of aggregates remain near the surface. This separation by sifting requires the tool moves slowly. By faster tilling, no segregation occurred because the movement of small particles to the bottom is disrupted by increasing the speed and therefore MWD increases in the subsoil (Heege and Vosshenrich, 1998). This result can be explained by the time needed for small particles to sift downward in voids behind tines. With fast-moving tines, this time will be too short for segregation to take place (Heege, 2013). Several studies have reported that MWD declined in the subsoil (Chen et al., 2009; Bogrekci and Godwin, 2007). Winged-Paraplow has the highest amount of fragmentation in all treatments and the Bentleg created the least amount of fragmentation, probably due to the wing mounted on Paraplow tine.
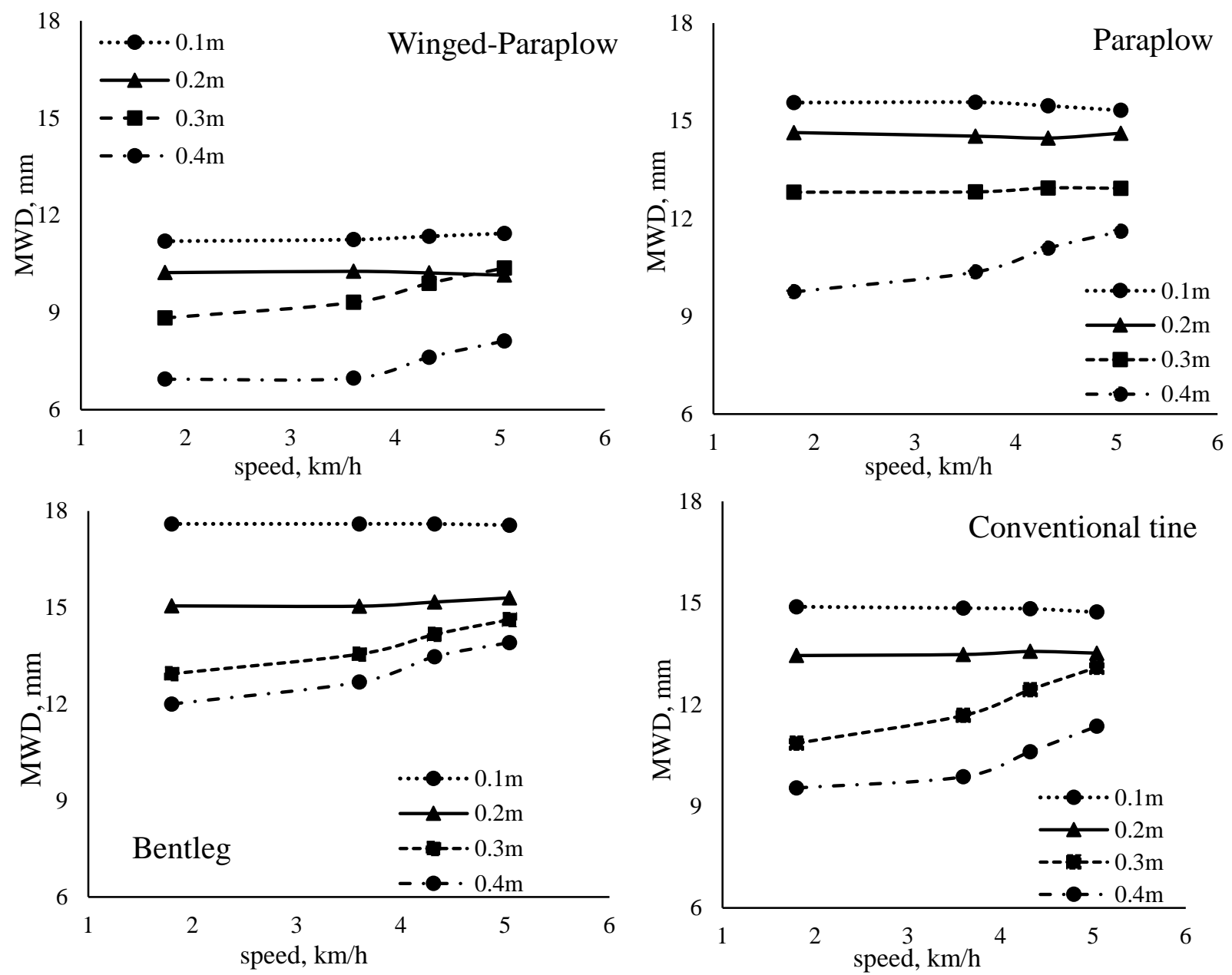

Figure 3. The triplet effect of forward speed $\times$ depth $\times$ tine type on MWD. 


\section{Effect of speed $\times$ depth $\times$ Moisture on MWD}

As shown in Fig. 4, it seems that the changes of forward speed have no significant effect on MWD, while in many articles the effect of the speed on soil fragmentation has been mentioned. To clarify the ambiguity, the triplet effect of speed $\times$ depth $\times$ Moisture was examined on MWD (Fig. 4).
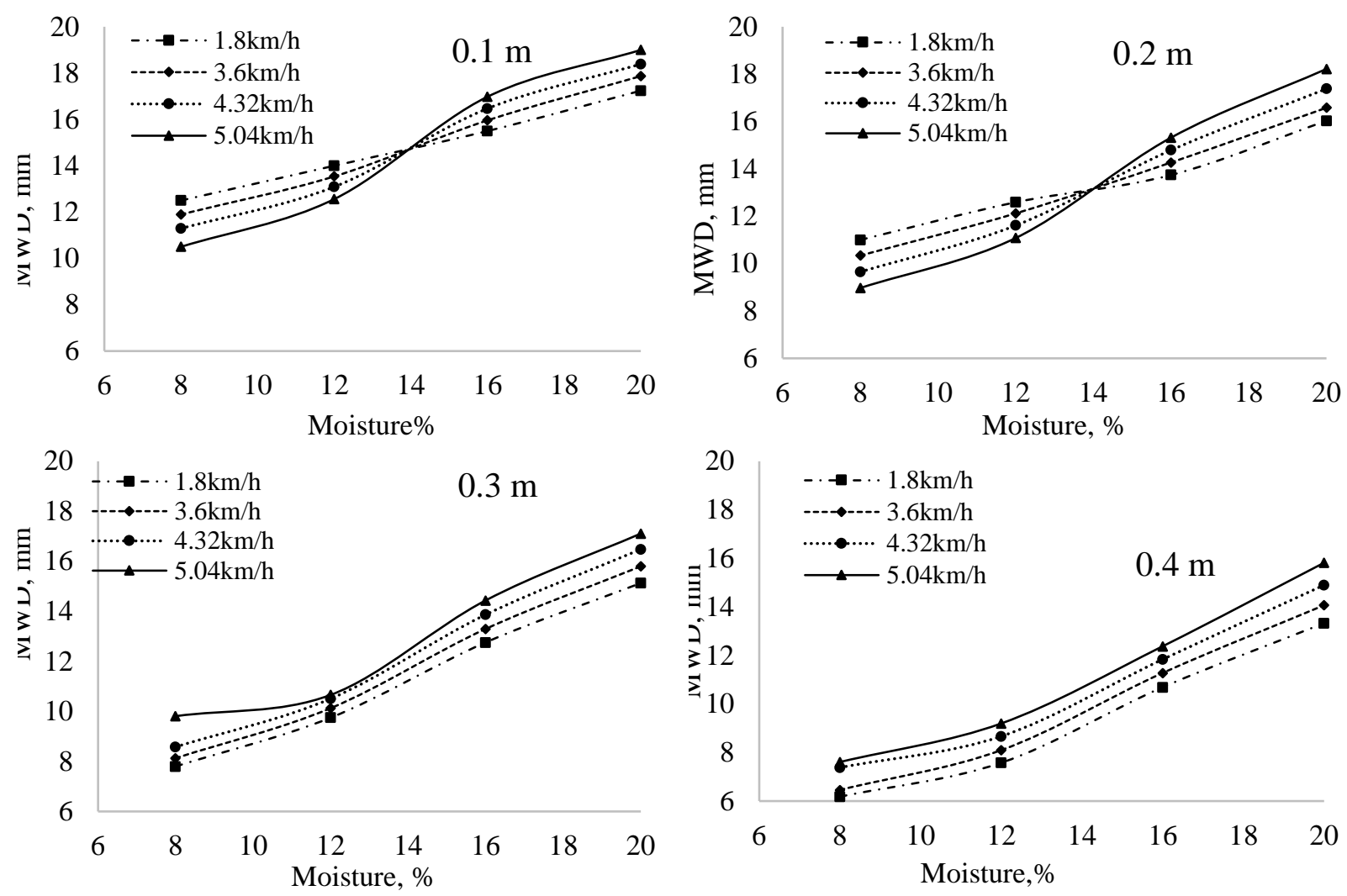

Figure 4 . The triplet effect of forward speed $\times$ depth $\times$ soil moisture on MWD.

In all tests, MWD increased with increasing moisture, in line with other studies (Hemmat et. al., 2007; Abbaspour-Gilandeh and Sedghi, 2015). The increase in MWD with increasing moisture can be attributed to a decrease in resistance of the soil against the tine movement; as a result, the soil is cut down instead of crumbling and larger clods are created. The noteworthy point in these diagrams is that at depths 10 and $20 \mathrm{~cm}$, in moisture contents of 8 and 12\%, MWD decreased with increasing speed but in moisture contents of 16 and 20, forward speed increased showed an inverse effect on MWD changes. The reason for this contradictory behavior is the fact that, in low moisture, crescent soil rupture of the soil occurs by the applied force from the tillage tool to the soil. Therefore, the dryer the soil, the more force needed to break the soil, which increased soil crumbling. However, in higher moisture contents, moving the soil over the tool surface will cause its fragmentation. In this regard, a lower soil movement speed will increase the time that soil stays on the tool and hence a greater fragmentation will happen. MWD at depths 30 and $40 \mathrm{~cm}$ in all moisture become larger with an increase in the speed since the time required sifting fine particle and moving them to larger depths decreases. In most of the previous works, with increasing speed, the amount of soil fragmentation increased, but the moisture content in their operating conditions was less than 12\% (McKyes, 1985; Ahaneku and Ogunjirin, 2005; Boydaş and Turgut, 2005).

\section{The Triple Effect of speed $\times$ tine type $\times$ Moisture on MWD}

For all tine types, MWD increases with increasing the moisture content. Fig. 5 illustrates that in moisture content of $8, \mathrm{MWD}$ is almost the same for all speeds. At moisture content less than 0.8PL 
at all speeds, the winged-Paraplow is able to provide proper aggregate size for seedbed. By simultaneous examining of Fig. 3 and 5, it can be concluded that the increase in speed does not have a significant effect on soil fragmentation; rather, the particle separation occurs completely at relatively low speeds. The soil particles are better sifted and the finer particles move toward subsoil and the coarser particles are left out in topsoil. Bentleg compared to other tines was less sensitive to moisture change and the difference between the minimum and maximum of MWD value was less. Conventional tine is very sensitive to changes in moisture content. At low moisture contents, it causes severe soil fragmentation while at high moisture content, it acts as a knife that cuts the soil slowly and causes less soil disturbance.
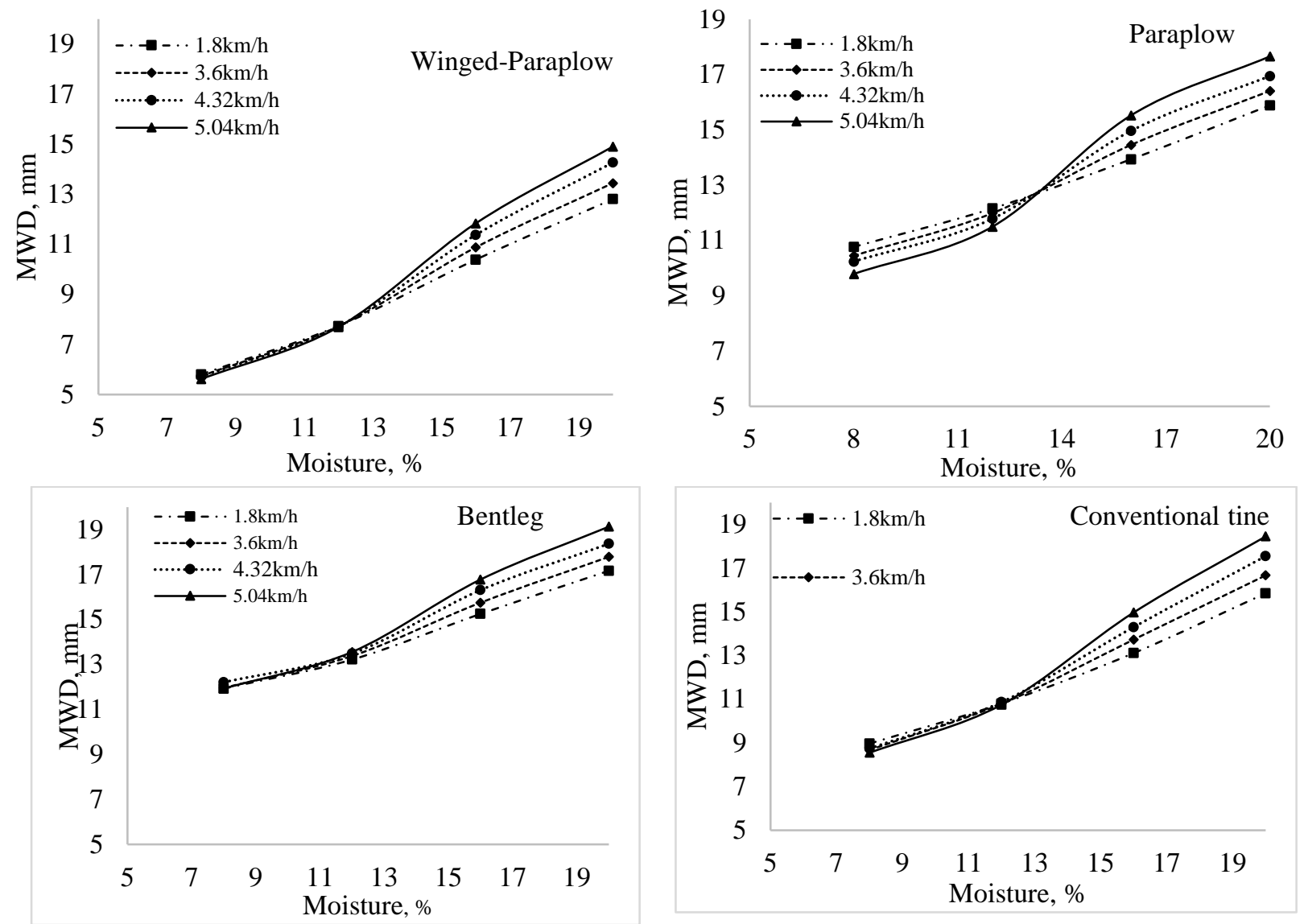

Figure 5. The triplet effect of forward speed×tine type $\times$ soil moisture on MWD.

\section{Discussion and Conclusion}

Because tilling by the Bentleg and the conventional tine leads to the formation of large clods, the Winged-Paraplow and Paraplow tines are preferred for subsoiling operations. In this way, it is possible to create a suitable seedbed considering the further soil crumbling. Winged-Paraplow further crumbled the soil compared to other tines and created proper soil fragments less than $8 \mathrm{~mm}$ at moistures content less than 0.8PL; hence, it is a suitable tool for proper plant growth and root development at any soil depth. Moreover, it created larger clods in topsoil area that prevented the soil erosion by wind and water.

At low speed as the tool cutting the soil, fine particles had a better chance than the larger ones to sift downward in voids; i.e., behind tines. Therefore, a larger number of large aggregates remain near the surface. This separation by sifting requires the tool moves slowly. With fast-moving tines, no segregation occurred because the movement of small particles to the bottom is disrupted by increasing speed and therefore MWD increases in the subsoil. With fast-moving tines, this time will be too short for segregation to take place. At low moisture contents, a high speed causes increased soil crumbling 
and reduced MWD while at high moisture content, by increasing speed, tine instead of crumbling the soil cut the soil like a knife, leading to large particles in the soil.

Bentleg compared to other tines was less sensitive to moisture change and the difference between the minimum and maximum of MWD value was less. Conventional tine is very sensitive to changes in the moisture content. At low moisture contents, it causes severe soil fragmentation while at high moisture contents it acts as a knife that cuts the soil slowly and causes less soil disturbance.

\section{References}

Abbaspour-Gilandeh, Y., \& Sedgh, R. (2015). Predicting soil fragmentation during tillage operation using fuzzy logic approach. J.Terramech. 57, 61-69.

Ahmadi, H., \& Mollazadeh, K. (2009). Effect of plowing depth and soil moisture content on reduced secondary tillage. Agric. Eng. Int.: The CIGR E Journal. 11, 1-9.

Ahaneku, I. E., \& Ogunjirin, O. A. (2005). Effect of tractor forward speed on sandy loam soil physical condition during tillage. Nigerian J. Tech. 24, 51-57.

Adam, K.M., \& Erbach, D.C. (1992). Secondary tillage tool effect on soil aggregation. Trans. ASAE. 35, 1771-1776.

Allmaras, R.R., Burwell, R. E., \& Holt, R.F. (1969). Plow layer porosity and surface roughness from tillage as affected by initial porosity and soil moisture at tillage time. Soil Sci. Soc. America Proc.31, 550-556.

Askari, M., Shahghol,i G., \& Abbaspour, Y. (2019).New wings on the interaction between conventional subsoiler and paraplow tines with the soil: effects on the draft and the properties of soil. Arch. Argon. Soil Sci. 65, 88-100.

Barzegar, A.R., Asoodar, M.A., Khadish, A., Hashemi, A.M., \& Herbert S.J. (2003). Soil physical characteristics and chickpea yield responses to tillage treatments. Soil and Till. Res. 71, 49-57.

Barzegar, A.R., Hashemi, A.M., Herbert S.J., \& Asoodar, M.A. (2004). Interactive effects of tillage system and soil water content on aggregate size distribution for seedbed preparation in Fluvisols in southwest Iran. Soil Till. Res.78, 45-52.

Berntsen, R., \& Berre, B. (1993). Fracturing of soil clods and the soil crumbling effectiveness of draught tillage implements. Soil Till. Res.28, 79-94.

Bogrekci, I.., \& Godwin, R.J. (2007). Development of an image-processing technique for soil tilt sensing. Biosys. Eng. 97, 323-331.

Braunack, M.V., \& Dexter, A.R. (1989). Soil aggregation in the seedbed: a review. II. Effect of aggregate sizes on plant growth. Soil Till. Res. 14, 281-289.

ChenHou, R., Gong, Y., Li, H., Fan, M., \& Kuzyakov, Y. (2009). Effects of 11 years of conservation tillage on soil organic matter fractions in wheat monoculture in Loess Plateau of China. Soil and Till. Res. 106, 85-94.

Czyż, EA., \& Dexter, A.R. (2009). Soil physical properties as affected by traditional, reduced and notillage for winter wheat. Int.Agrophys. 23, 319-326.

Dalla Rosa, J., Cooper, M., Darboux, F., \& Medeiros, J.C. (2012). Soil roughness evolution in different tillage systems under simulated rainfall using a semivariogram-based index. Soil Till. Res. 124, 226-232.

Ghadernejad, K., Shahgholi, G., Mardani, A., \& Ghafouri Chiyaneh, H. (2018). Prediction effect. farmyard manure, multiple passes and moisture content on clay soil compaction using adaptive neuro-fuzzy inference system. J.Terramech. 77, 49-57.

Gill, W. R., \& McCereery, W. F. (1960). Relation of size of cut to tillage tool efficiency. Agric. Eng. 41, 372-374.

Godwin, R. J. (2007). A review of the effect of implement geometry on soil failure and implement forces. Soil Till. Res. 97, 331-340.

Boydaş, M. G., \& Turgut, N (2007). Effect of Tillage Implements and Operating Speeds on Soil Physical Properties and Wheat Emergence. Turkish J. Agric. For.31, 399-412.

Hakansson, I, Myrbeck A, \& Etana, A. (2002). A review of research on seedbed preparation for small grains in Sweden. Soil Till. Res.64, 23-40. 
Heege, HJ., \& Vosshenrich, H.H. (1998). Soil Cultivation: New Methods and New Technologies. In Clubof Bologna, Proceedings of the 9th meeting, Bologna, 15-16 Nov 1998 (EditioneUnacoma Service srl), pp. 53-64.

Heege, H. J. (2013). Precision in Crop Farming. Site Specific Concepts and Sensing Methods: Applications and Results. Springer, United States.

Hemmat, A., Ahmadi, I., \& Masoumi, A. (2007). Water infiltration and clod size distribution as influenced by ploughshare type, soil water content and ploughing depth. Biosys. Eng. 97, 257266.

Kabiri, K., \& Zarean, S. (2002). Evaluation of draft requirement and soil inversion of moldboard plow at different levels of speed and plowing depth. J. Agric. Sci. Nat. Res. 9, 129-138.

Kemper, W D. \& Rosenau, R C. (1986). Aggregate stability and size distribution. In: Klute, A. (Ed.), Methods of Soil Analysis. Part 1. Physical and Mineralogical Methods. ASA-SSSA, Madison, WI, pp. 425-440.

Kemper, W D., \& Chepil, WS. (1995). Size distribution of aggregates. Second Ed. In: Black, C.A. (Ed.), Methods of Soil Analysis. Part I: Physical and Mineralogical Properties, second ed., SSSA, Madison, WI, pp. 498-519.

McKyes, E., \& Maswaure, J. (1997). Effect of design parameters of flat tillage tools on loosening of a clay soil. Soil Till. Res. 43, 195-204.

McKyes, E. (1985). Soil Cutting and Tillage. Developments in Agricultural Engineering. Elsevier, Amsterdam.

Munkholm, L. J. (2002). Soil Fragmentation and Friability. Effects of soil water and soil management. danish institute of agricultural sciences, department of crop physiology and soil science (Ph.D. Thesis).

Murungu, F S., Nyamugafata, P., Chiduza. C., Clarck, L J. \& Whalley, W R. (2003). Effect of seed priming, aggregate size and soil matric potential on emergence of cotton (Gossypiumhirstum L.) and maize (Zea mays L.). Soil Till. Res. 74, 161-168.

Nasr, H M., \& Selles, F. (1995). Seedling emergence as influenced by aggregate size, bulk density, and penetration resistance of the seedbed. Soil Till. Res. 34, 61-76.

Ling, R. F., \& Roberts, H. V. (1975). IDA: an approach to interactive data analysis in teaching. J. Bus. 48, 411-451.

Ojenigi, S. O., Dexter A R (1979). Soil factors affecting the macro structure produced by tillage. Trans of the ASAE.22, 339-343.

Rahimi-Ajdadi F., \& Abbaspour-Gilandeh, Y. (2011). Artificial Neural Network and stepwise multiple range regression methods for prediction of tractor fuel consumption. Measurement. 44, 21042111.

Russell, E. W. (1973). Soil Conditions and Plant Growth, 10th ed. Longman, Green and Co., London (849 pp.).

Salar, M. R., Esehaghbeygi, A., \& Hemmat, A. (2014). Soil loosening characteristics of a dual bent blade subsurface tillage implement. Soil Till. Res.134, 17-24.

Slowinska, A., (1994). Changes in structure and physical Properties of soil during spring tillage operations. Soil Till. Res. 29, 397-407.

Tahan, Y. H., Hassan, A., \& Hammadi, A. (1992). Effect of plowing depths using different plow types on some physical properties of soil. A. M. A. 23, 21-24.

Woodruff, D. W., Lewellen, R. T., Duffas, J. E., \& Whitney, E. D. (1986.) An investigation into the effects of soil compaction and irrigation on sugar beet infected with rhizomania. Soil Till.Res. 21, 353-360. 